\title{
National Achievement Award, Canadian Linguistic Association Prix national d'excellence, Association canadienne de linguistique 2021
}

\section{DR. JOHN ARCHIBALD}

Dr. John Archibald has demonstrated leadership in linguistics in Canada and has made substantial and distinguished contributions to language research over a significant period. He has exhibited innovation, and has impacted practice, policy, and the broader community; he has also been effective in communication and popularization beyond academia. In short, he is an extraordinary academic leader, educator and scholar who has made great contributions to the field within Canada and around the world.

Dr. Archibald earned his Ph.D. in 1991 at the Modern Language Centre in O.I.S.E, after completing his BA and MA, also at the University of Toronto. He is currently Professor at the University of Victoria, where he has served as Dean of Humanities. Prior to this position, he was Department Head and Associate Dean at the University of Calgary. He is also an affiliate researcher at the Bilingualism Research Lab at the University of Illinois at Chicago. He served as President of the Canadian Linguistic Association from 2002 to 2005, and in 2020 he was inducted as a Fellow into the Royal Society of Canada.

Dr. Archibald's research focusses on second language phonology, with five books and many published articles and presentations in this area. His groundbreaking 1993 monograph Language Learnability and L2 Phonology was the first to adapt models of language learnability to the question of how second-language learners acquire phonological knowledge, taking seriously the notion of L2 phonology as cognition. His approach laid the groundwork for much future research on interlanguage grammars and the architecture of the bilingual mind, and is regularly covered in textbooks in the field. In his current work, he is probing recursion and representational realism through research on second language acquisition at the interfaces of morphology and syntax. In addition to his own research, Dr. Archibald has served the field as a reviewer, adjudicator, and editor.

Dr. Archibald is also an extremely effective bridge-builder, bringing together the worlds of theoretical linguistics and L2 pedagogy. He has influenced thousands through his work on the benefits of second language education and bilingualism, including the production of the video Advantage for Life: Learning Another 
Language, which was placed in every school in Alberta. He also co-developed a certificate program in Alberta for heritage language teachers, as well as co-producing several technical reports for the government on aspects of second language learning such as instructional time, special populations, and indigenous populations. His work has thus shaped educational policy in the province of Alberta.

Archibald has also excelled as an advisor and mentor, fostering new generations of L2 phonology scholars. Since 2000, he has been a co-editor of the widely used textbook, Contemporary Linguistic Analysis, now in its 9th edition, which showcases Canadian linguistics and brings new students into the field. Notably, Dr. Archibald has taught introductory linguistics almost every year (even while Dean) for almost 30 years, earning exemplary student evaluations.

To sum up, John Archibald has made defining contributions to linguistics in a multifaceted manner, advancing the science of second language phonology and the scholarship of teaching. He has been a leader in knowledge mobilization to both community members and policy makers. The Canadian Linguistic Association is delighted to recognize this great service by awarding Dr. Archibald the National Achievement Award for 2021.

$$
* * *
$$

\section{Professeur John Archibald}

Le professeur John Archibald a fait preuve de leadership en linguistique au Canada et a apporté, au cours d'une longue période, des contributions considérables et précieuses au domaine de la recherche. Il a aussi fait preuve d'innovation et a influencé la pratique, la politique, et la communauté en général. Il a été un très efficace communicateur et vulgarisateur bien au-delà du milieu académique. En bref, il est un chef de file universitaire, un enseignant exceptionnel et un savant qui a contribué généreusement au domaine de la linguistique au Canada et dans le monde.

Le professeur Archibald a obtenu son doctorat en 1991 au Centre de langues modernes de l'Institut d'études pédagogiques de l'Ontario, après avoir obtenu son baccalauréat et sa maîtrise, également à l'Université de Toronto. Il est actuellement professeur à l'Université de Victoria, où il a été aussi doyen de la faculté des sciences humaines. Avant d'être nommé à ce poste, il avait été directeur du département et doyen associé à l'Université de Calgary. Il est aussi chercheur affilié au Laboratoire de recherche sur le bilinguisme à l'Université d'Illinois à Chicago. Il a été président de l'Association canadienne de linguistique de 2002 à 2005, et est devenu en 2020 membre de la Société royale du Canada.

La recherche de John Archibald est axée sur la phonologie des langues secondes; il a publié cinq livres et a rédigé un grand nombre d'articles et de présentations dans le domaine. Sa monographie révolutionnaire de 1993 Language Learnability and L2 Phonology a été le premier ouvrage à adapter des modèles d'apprentissage à la manière dont les apprenants d'une langue seconde acquièrent des connaissances phonologiques, en prenant au sérieux le concept de la phonologie de langue seconde en tant que cognition. Son approche a préparé le terrain pour beaucoup de travaux de recherche ultérieurs sur la grammaire de l'interlangue et l'architecture du cerveau 
bilingue, et figure dans beaucoup de manuels dans le domaine. Dans son travail actuel, il étudie la récursion et le réalisme représentationnel à travers la recherche sur l'acquisition d'une langue seconde à l'interface de la morphologie et de la syntaxe. En plus de sa propre recherche, le professeur Archibald a également été examinateur, arbitre et rédacteur.

Par son travail, John Archibald est à la croisée de plusieurs domaines, réunissant les mondes de la linguistique théorique et de la pédagogie de langue seconde. Il a influencé des milliers de personnes à travers son travail sur les avantages de l'instruction des langues secondes et du bilinguisme, y compris la production de la vidéo Advantage for Life: Learning Another Language, qu'on retrouve dans chaque école de l'Alberta. Il a aussi co-développé le programme de certification en Alberta pour les enseignants de langues patrimoniales et a coproduit pour le gouvernement plusieurs rapports techniques sur divers aspects de l'apprentissage d'une langue seconde, comme le temps d'enseignement, les populations particulières et les populations autochtones. Son travail a ainsi contribué à former la politique d'éducation de la province de l'Alberta.

John Archibald a également excellé en tant que conseilleur et mentor, en appuyant les nouvelles générations de chercheurs en phonologie des langues secondes. Depuis l'année 2000, il est corédacteur du réputé manuel intitulé Contemporary Linguistic Analysis, qui en est à sa $9^{\mathrm{e}}$ édition; cet ouvrage met en valeur la linguistique canadienne et amène de nouveaux étudiants au domaine. Le professeur Archibald a donné presque chaque année (même en tant que doyen) un cours d'introduction à la linguistique, et ce pendant 30 ans, en obtenant toujours, de la part de ses étudiants, d'excellentes évaluations.

En résumé, John Archibald a apporté des contributions durables et variées à la linguistique, en faisant progresser la science de la phonologie des langues secondes tout autant que la recherche relative à l'enseignement. Il a été un chef de file dans la mobilisation des connaissances à l'égard des membres de la communauté et des décideurs politiques. L'Association canadienne de linguistique est ravie de reconnaître ces vastes services rendus en décernant à John Archibald le Prix national d'excellence pour 2021. 
DR. JOHN ARCHIBALD

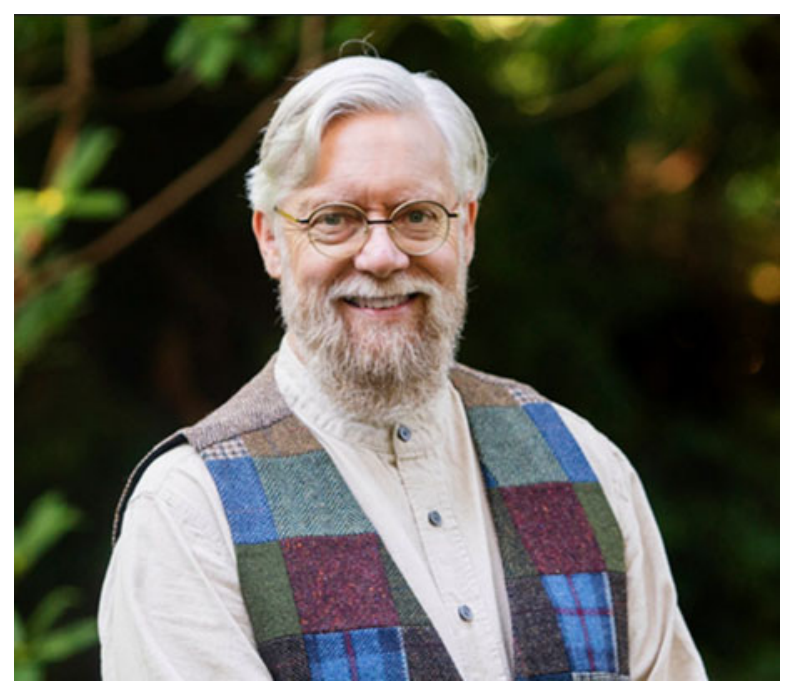

Professeur John Archibald 


\section{Early Career Researcher Award, Canadian Linguistic Association \\ Prix du chercheur ou de la chercheuse en début de carrière, Association canadienne de linguistique 2021}

\section{DR. HEATHER BLISS}

Dr. Heather Bliss is an early career researcher who has made original and important contributions in research across a number of subfields, including syntax, morphology, phonetics, and language documentation and revitalization. At the same time, she has had lasting impacts in the areas of knowledge translation, community engagement, and policy surrounding Indigenous languages in Canada, particularly for Blackfoot, an Algonquian language.

Dr. Bliss received her Ph.D. in linguistics from UBC in 2013, after completing her BA and MA at the University of Calgary. She is currently a Lecturer at Simon Fraser University, and she holds adjunct positions at the University of Calgary, at UBC, and at the University of Victoria. She has held a Banting Postdoctoral Fellowship and a SSHRC Postdoctoral Fellowship, and was a Finalist for the 2014 SSHRC Talent Award. She has also been awarded many grants for fieldwork, conferences, and research, including two SSHRC Connection Grants. She won the Most Impactful Paper Award at the 7th International Conference on Language Documentation and Conservation in 2021. In addition to her research, Dr. Bliss has a rich and varied profile as a teacher and undergraduate advisor and mentor, and has also proven her talents as a reviewer, editor, and workshop organizer.

Dr. Bliss's work has been presented and published in high-profile venues, and it covers topics such as configurationality, inverse systems, pseudo-incorporation, pronouns, demonstratives, and nominalization. In the area of articulatory phonetics, she has co-authored articles on phonetic fieldwork, soundless vowels, and the use of ultrasound in teaching the pronunciation of Indigenous languages. She is currently writing chapters on determiners and on polysynthesis. Dr. Bliss's scholarly contributions also extend to language documentation and revitalization. She is the Editor and Curator of the Blackfoot Stories Archive, and she publishes on Indigenous language learning, and on the topic of credit and authorship in work on Indigenous languages.

Dr. Bliss's research combines in-depth knowledge of linguistic theory and multiple methodologies, from targeted elicitation techniques in fieldwork to the collection of rich naturalistic documentary data. She has innovated data collection techniques that serve the additional goal of language revitalization. In particular, her Blackfoot Online Stories Archive project has brought together Blackfoot speakers of various ages and fluency levels in a community setting. She has excelled in knowledge translation on multiple fronts, including creating and preparing research 
reports for Indigenous organizations; creating, curating, or contributing to a number of online resources; giving numerous media interviews; and undertaking a wide variety of public outreach activities, including activities intended for Indigenous youth.

In summary, Heather Bliss is an extraordinary early career researcher who has already achieved distinction in a range of areas, including theoretical linguistics and language documentation, while also demonstrating innovation in teaching and community outreach. The Canadian Linguistic Association is delighted to recognize Dr. Bliss by awarding her the Early Career Researcher Award in 2021.

$$
* * *
$$

\section{Professeure Heather Bliss}

La professeure Heather Bliss, une chercheuse en début de carrière, a déjà contribué de manière originale et importante à de nombreux domaines de recherche, y compris la syntaxe, la morphologie, la phonétique, et la documentation et préservation des langues. Elle a également eu un impact durable dans les domaines de la traduction, de l'engagement communautaire, et de la politique entourant les langues autochtones au Canada, en particulier le blackfoot, une langue algonquienne.

Heather Bliss est titulaire depuis 2013 d'un doctorat en linguistique de l'Université de la Colombie-Britannique, après avoir obtenu son baccalauréat et sa maîtrise à l'Université de Calgary. Elle est présentement professeure chargée de cours à l'Université Simon Fraser, et détient des postes de professeure adjointe à l'Université de Calgary, à l'Université de la Colombie-Britannique et à l'Université de Victoria. Elle s'est vu octroyer une bourse postdoctorale Banting et une bourse postdoctorale du CRSH, et comptait parmi les finalistes pour le prix Talent du CRSH en 2014. Elle a également obtenu de nombreuses subventions pour le travail de terrain, les conférences, et la recherche, incluant deux subventions du programme Connexion du CRSH. Elle a gagné le prix de l'article le plus influent à la $7^{\mathrm{e}}$ Conférence internationale de la documentation et préservation des langues (ICLDC) en 2021. En plus de sa recherche, Heather Bliss affiche un profil riche et varié en tant qu'enseignante, conseillère et mentore du premier cycle, ce à quoi elle ajoute des fonctions d'examinatrice, de rédactrice, et d'organisatrice d'ateliers. Son travail a été présenté et publié dans des revues renommées et inclut les sujets tels que la configurationalité, les systèmes inverses, la pseudo-incorporation, les pronoms, les démonstratifs, et la nominalisation. Dans le domaine de la phonétique articulatoire, elle a corédigé des articles sur le travail de terrain phonétique, les voyelles silencieuses, et l'usage des ultrasons dans l'enseignement de la prononciation des langues autochtones. Elle est en cours de rédaction de chapitres sur les déterminants et la polysynthèse. Les contributions universitaires de Heather Bliss s'étendent aussi aux domaines de la documentation et la préservation des langues. Elle est rédactrice et conservatrice de l'archive des histoires d'origine blackfoot, et elle publie des travaux sur l'apprentissage des langues autochtones ainsi que sur le sujet de l'attribution et du statut d'auteur dans les travaux sur des langues autochtones. 
La recherche de la professeure Bliss combine des connaissances approfondies de la théorie linguistique et de plusieurs méthodologies, qui vont des techniques d'élicitation ciblées dans le travail de terrain jusqu'à la collection des données documentaires naturelles. Elle est un fer de lance de techniques novatrices de collection de données, qui servent en outre la cause de la revitalisation des langues. En particulier, son projet d'une archive en ligne des histoires blackfoot a rassemblé dans un environnement communautaire des locuteurs du blackfoot de plusieurs âges et de différents niveaux de maîtrise. Elle a excellé dans la transmission des connaissances sur plusieurs fronts, y compris la création et la préparation de rapports de recherche pour des organisations autochtones; dans la création, la conservation, ou la contribution à de nombreuses ressources en ligne; en accordant de nombreuses entrevues avec les médias; et en entreprenant une grande variété d'actions de portée publique, dont des activités s'adressant aux jeunes autochtones.

En résumé, Heather Bliss est une chercheuse en début de carrière qui s'est déjà distinguée dans une série de domaines, dont la linguistique théorique et la documentation des langues, tout en faisant preuve d'innovation dans les domaines de l'enseignement et du rayonnement communautaire. L'Association canadienne de linguistique est ravie de reconnaître la professeure Bliss en lui attribuant le prix de chercheuse en début de carrière pour 2021. 
DR. HEATHER BLISS

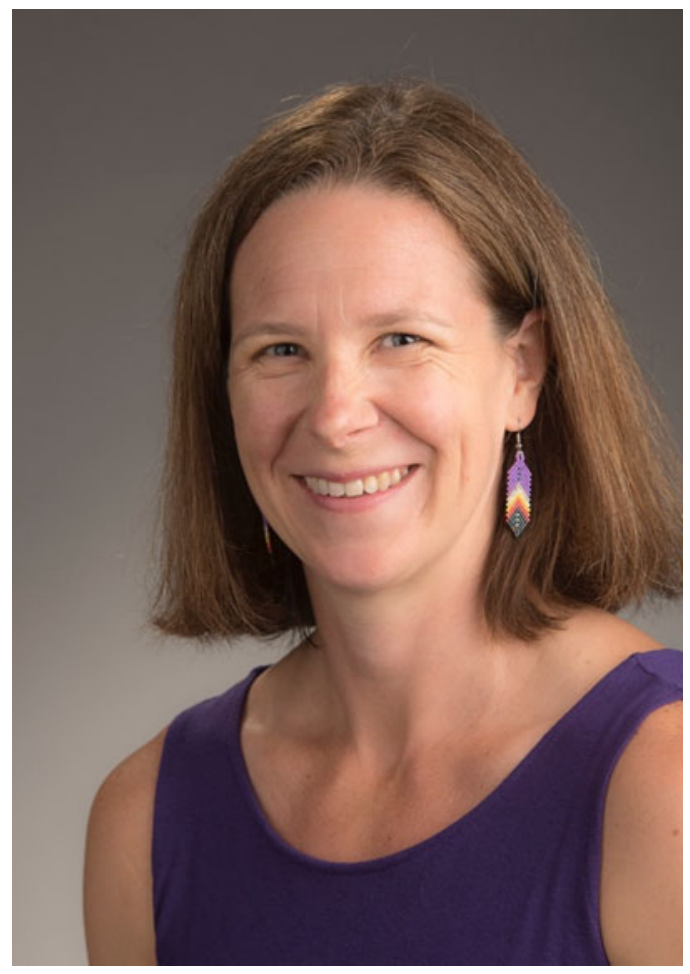

Professeure Heather Bliss 


\section{Student Achievement Awards, Canadian Linguistic Association Prix d'excellence étudiant, Association canadienne de linguistique 2021}

\section{Best presentation/ Meilleure communication}

Cheman Baira A Sangma (University of Calgary): “Garo gemination: A case of faithfulness producing non-moraic geminates"

Cheman Baira Sangma gave an excellent talk on gemination in Garo, an underdocumented Sino-Tibetan language. It presented novel data with notable typological implications that were clearly laid out. The talk addressed big picture issues and generated many interesting questions around the conclusions. In the question period he demonstrated clear competence with respect to both the language facts and the theoretical issues.

Cheman Baira Sangma a donné une excellente présentation sur la gémination en garo, une langue sino-tibétaine sous-documentée. De nouvelles données, porteuses d'implications typologiques importantes, ont été présentées avec une belle clarté. La présentation a abordé des sujets de grande envergure et a généré de nombreuses questions autour des conclusions proposées. Pendant la période des questions, Cheman a clairement démontré sa compétence quant aux faits de langue du garo, mais aussi en matière des questions théoriques.

\section{Honourable mentions / Mentions honorables}

Claire Djuikui Dountsop (Université de Montréal): « Trajectoire de l'omission de il dans les constructions impersonnelles à Montréal »

Dakota Wing et Ana-Maria Jerca (York University): “ 'You were really good for your first time in English': Raciolinguistic discourse, accommodation, and gatekeeping surrounding Harnarayan Singh's English Canadian NHL broadcasts”

\section{Meilleure affiche / Best poster}

Brittney O'Neill (York University): “The Dance of Conversation: Gender and Language in Metaphors for West Coast Swing Partnership"

Brittney O'Neill's poster provided an analysis of metaphors used to describe partner roles in the West Coast Swing dance community. The presentation was exceptionally 
clear, concise, and engaging. The topic was original and the conclusions drawn from the data presented were well motivated within the context of metaphor theory. Overall, this displayed an excellent work in progress.

$$
* * *
$$

L'affiche de Brittney O'Neill proposait une analyse des métaphores utilisées pour décrire les rôles des partenaires engagés dans la communauté du West Coast Swing. La présentation était exceptionnellement claire, concise, et stimulante. Le sujet était original et les conclusions proposées à partir des données présentées étaient très bien motivées dans le contexte de la théorie des métaphores. En résumé, il s'agissait d'une excellente présentation de travail en cours.

\section{Honourable mention / Mention honorable}

David Rosychuk (University of Alberta): «L'avenir dans l'Ouest: la référence temporelle au futur en français albertain »

\section{Appreciation for Extraordinary Volunteerism / Appréciation pour bénévolat extraordinaire}

We would like to thank two people this year for going above and beyond for the Canadian linguistic community.

First, we would like to thank Bronwyn Bjorkman for her exceptional commitment to the CLA. This is evident in all the extra organizational work that she has done for both the 2020 and 2021 online CLA meetings. Bronwyn has made our meetings not only possible and seamlessly-run, but also fun and a joy to attend. In addition to this work, Bronwyn has been central in the running of many other conferences and works tirelessly to ensure that linguistics events are accessible to all.

We would also like to thank Daniel Currie Hall for his exceptional commitment to the CLA. Daniel has run the CLA website for 11 years and has just moved us to a new server and overhauled the entire site. It is a crucial hub for linguistics in Canada and we rely on it and on Daniel constantly. Daniel also offers technical help to the Journal and has created the Latex files that many of you have used.

The CLA could not function at the level it does without the tireless work of members like Bronwyn and Daniel. Thank you to you both, especially for your recent work that goes above and beyond all of our expectations!

***

Nous tenons à remercier cette année deux personnes qui se sont surpassées pour la communauté linguistique canadienne. 
Tout d'abord, nous tenons à remercier Bronwyn Bjorkman pour son engagement exceptionnel envers l'ACL. Cet engagement est illustré par tout le travail organisationnel supplémentaire qu'elle a effectué pour les conférences en ligne de l'ACL en 2020 et 2021. Bronwyn a largement contribué à rendre nos réunions non seulement possibles et exécutées sans failles, mais tout ce qu'il y a d'agréable. En plus de ce travail pour l'ACL, Bronwyn a joué un rôle central dans le déroulement de nombreuses autres conférences et elle travaille sans relâche afin que les événements linguistiques soient accessibles à tous.

Nous tenons également à remercier Daniel Currie Hall pour son engagement exceptionnel envers l'ACL. Daniel gère depuis 11 ans le site Web de l'ACL et il vient de nous déplacer vers un nouveau serveur et de remanier l'ensemble du site. $\mathrm{Ce}$ site Web est un point de rencontre crucial pour la linguistique au Canada et nous comptons constamment sur le site ainsi que sur Daniel. Daniel offre également une aide technique à la revue et a créé et mis à jour les fichiers Latex que beaucoup d'entre vous ont utilisés.

L'ACL ne pourrait pas fonctionner comme il le fait sans le travail inlassable de membres comme Bronwyn et Daniel. Merci à vous deux, surtout pour votre récent travail qui va au-delà de toutes nos attentes! 